\title{
Analysis of GHG Emissions for City Passenger Trains: Is Electricity an Obvious Option for Montreal Commuter Trains?
}

\author{
Sabrina Chan ${ }^{1 *}$, Luis Miranda-Moreno ${ }^{1}$, Zachary Patterson ${ }^{2}$ \\ ${ }^{1}$ Department of Civil Engineering and Applied Mechanics, McGill University, Montreal, Canada \\ ${ }^{2}$ Department of Geography, Planning and the Environment, Concordia University, Montreal, Canada \\ Email: "sabrina.chan@mail.mcgill.ca, luis.miranda-moreno@mcgill.ca, zachary.patterson@concordia.ca
}

Received November 9, 2012; revised January 15, 2013; accepted January 25, 2013

Copyright (C) 2013 Sabrina Chan et al. This is an open access article distributed under the Creative Commons Attribution License, which permits unrestricted use, distribution, and reproduction in any medium, provided the original work is properly cited.

\begin{abstract}
Alternative technologies have emerged to reduce the greenhouse gas (GHG) emissions of traditional commuter rail systems powered by diesel. Even larger reductions can be obtained with energy production from renewable resources. This paper uses the commuter rail system in Montreal, Quebec, as a case study for implementing alternative technologies, namely, complete electrification of the network (only one of the existing five lines is electrified) and hydrogen fuel cell-powered trains. It is important to note that the main source of electricity generation in Quebec is hydropower which is offered at a relatively low cost. Several criteria were considered to determine the most suitable alternative including GHG emissions from operation and fuel production, operation and capital costs, and technological and commercial viability. Electrification of the commuter rail system would decrease annual emissions by $98 \%$ which is more than 27,000 tons. The GHG reductions for hydrogen trains are lower than electric trains but still substantial. The operation costs favor the electrification scenario; however, the high costs of electrical infrastructure make hydrogen trains more competitive since additional infrastructure is unnecessary. However, hydrogen trains remain a new and unproven technology; uncertainties associated with it should be settled before full implementation.
\end{abstract}

Keywords: Alternative Technologies; Commuter Rail; Greenhouse Gases

\section{Introduction}

Rail transit has gained popularity in recent years, providing accessibility and mobility to populations outside the core of metropolitan areas; however, they require large investments for the construction of infrastructure including railways, electrical feeder systems, stations and maintenance yards. In some cases, it also involves acquiring land to build new rail infrastructure operating on grade-separated right-of-ways, away from vehicular traffic. Despite these drawbacks, rail systems have the capability of moving mass numbers of commuters: 1500 [1] compared to 200 persons per hour per foot width of road for cars assuming single occupancy [2]. Diesel commuter trains were also found to have lower pollutant emissions than private automobiles by 5.5 times per passenger-mile, in 1976, for an occupancy of 1.4 passengers/car and 223 passengers/train [3]. These factors are still apparent today; however, they are very sensitive to passenger loads and

"Corresponding author. distances travelled. For an occupancy rate of 1.6 passengers/car and 66 passengers/train, a car consumes 2.7 times more energy, emits 3.1 times more greenhouse gases and emits 8.5 times more pollutants than a diesel heavy rail train per passenger-miles travelled [4].

The main reluctance for rail development is the high cost of infrastructure which is about 16 times more expensive than roads per unit length [1]. These investments are only justified economically and socially if sufficient passenger demand exists. As a result, variations of the conventional heavy rail transit (HRT) have been developed such as the light rail transit (LRT) and high speed rail (HSR) in order to reduce costs and travel time. Although, the application of HSR is only appropriate for trips between metropolitan cities [5]. Other benefits include increased accessibility and mobility, reduced congestion and lower air pollution [6]. The implementation of new technologies such as electric and fuel cell systems has made rail transit even more attractive from an environmental perspective by further decreasing greenhouse 
gas (GHG) [7,8] and pollutant emissions [9]. For example, when hydrogen in a fuel cell is used to generate electricity or combusted with air, the only by-products are water, heat and low-levels of NOx, depending on the source of hydrogen and its impurity [9].

Some previous works have looked at the impact of new technologies in commuting train systems in Canada $[7,8,10]$. One study analyzed multiple hydrogen production techniques from renewable and non-renewable sources for internal combustion engines and fuel cell systems, and compares them to diesel and electric trains [10]. However, few studies have looked at life cycle analysis, including train manufacturing and infrastructure construction components, coupled with life cycle costs in order to make sustainable decisions. Also, there are few studies that analyze a combination of both new technologies and ridership management policies to reduce $\mathrm{GHG}$ emissions. Due to the dominance of coal-based electricity generation plants, no studies to our knowledge compare technologies with electricity produced from renewable energy which is common in Europe and in Quebec. With the advent of hydrogen technology, it is worthwhile to investigate its viability for the commuter rail in Montreal, Quebec, given its renewable electricity production.

Accordingly, the objectives of this paper are to: 1) evaluate GHG emissions of the commuter rail in Montreal for the current technology (diesel) and compare them with emissions under three other scenarios: two considering alternative technologies (hydrogen and electric) and a third involving changes in the ridership; and 2) estimate operation and capital costs of the implementation of the alternative technologies.

The paper is divided into eight sections. The following section briefly presents the alternative technologies. The third section presents a literature review on previous studies investigating the emissions impacts of alternative commuter train technologies. The fourth section introduces our case study and the fifth section describes the scope and limitations of the paper. The GHG emissions estimation approach for the different scenarios is found in Section 6. Section 7 discusses the results of the GHG calculations. Conclusions are provided in the last section.

\section{Popular Commuter Train Technology}

The main locomotive technology used for commuter rail systems in North American cities is diesel-powered. An alternative technology that has been around for some time, and is currently in use in some North American rail services is the electric-powered train. A third technology that has started to appear as a feasible alternative in the long-term is hydrogen fuel cell-powered trains. These three technologies are illustrated in Figure $\mathbf{1}$ and briefly described in this section [11].

\subsection{Diesel-Powered Trains}

The standard technology for commuter rail in North America is the diesel locomotive hauled coach trains. Diesel locomotives consist of a prime mover, traction

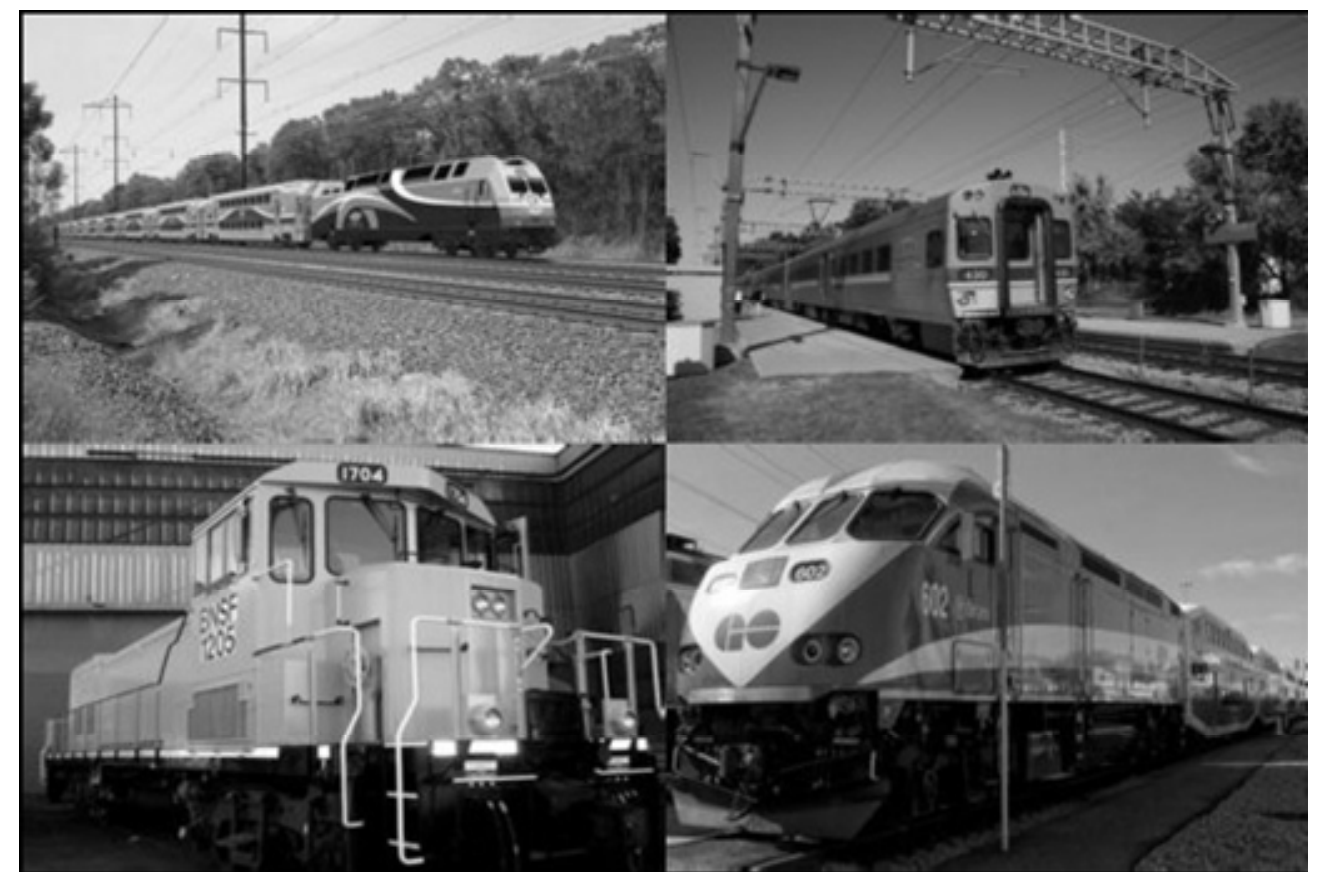

Figure 1. Train technologies (clockwise from top left): diesel-electric locomotive, electric multiple units, diesel locomotive, and fuel cell switch engine. 
motors (which use electricity), fuel tank and operator controls to push or pull passenger cars and coach cabs along railways.

This configuration does not require additional infrastructure for power supply although refueling stations are still needed. This traditional approach to commuter rail services is mainly due to low capital costs, low risk, quick delivery and its flexibility to rail operators. Despite these advantages, the performance of diesel trains in terms of power, acceleration and speed, is low compared to electrified trains. Due to the combustion of fossil fuels during rail operation, diesel-powered train is the most polluting compared to electric trains using renewable or non-renewable electricity production and hydrogen fuel cell powered trains.

Another diesel rail technology is the diesel multiple units (DMU) which are self-propelled and powered by one or more diesel engines. DMUs can have a variety of transmission types such as mechanical, electrical and hydraulic. Its performance is better than diesel locomotives due to faster acceleration and good adhesion on steep grades but inferior to electric multiple units (EMU). This would be a practical and cost-efficient alternative for short trains consisting of a maximum of 4-6 units.

\subsection{Electric-Powered Trains}

Electric commuter trains are rare in North America; however, they are quite common in Europe. There are two types of technology for electric trains: electric locomotives or EMUs which are self-propelled electric vehicles. Unlike diesel locomotives, electric locomotives do not carry prime movers on-board. Both electric technologies obtain energy from an off-car electrified traction power supply and distribution systems such as overhead catenary wires, or a third-rail system in which electrical infrastructure is placed on the ground alongside existing railway tracks.

Electrified trains offer many benefits including lighter weight, higher speed, higher system capacity and faster travel times. Electric locomotives can use renewable energy sources which would result in zero tailpipe emissions. Indirect emissions from electric propulsion, i.e. at the power plant, are minimal; however, most electricity generation plants in the United States are coal-powered.

EMUs are expensive and the high costs are only justified by high ridership levels and high frequency service. The Deux-Montagnes commuter rail line in Montreal is one such example.

\subsection{Hydrogen Fuel Cell-Powered Trains}

Hydrogen fuel cell technology converts stored hydrogen into electricity. It is a clean process as it only emits water vapor. One clear advantage over electric trains is that it is compatible with existing railways and additional infrastructure for power supply is not necessary which would lower infrastructure costs. The main drawbacks of hydrogen fuel cell are the space needed to store hydrogen tanks on-board as well as the risk of explosion upon collision.

This is an emerging technology for commuter rail and has not yet been proven; although, the commercial availability of hydrogen gas is possible. The world's first hydrogen fuel cell hybrid train was developed by the East Japan Railway Company (JR East) in 2006. Vemb-Lemvig-Thyborøn Jernbane (VLTJ) is in the process of launching Europe's first hydrogen powered train in Denmark. Also, Bombardier and the Ontario Ministry of Transport are currently studying the feasibility of a hydrogen-powered passenger train.

\section{Literature Review}

In the current context, the positive impact of new transportation technologies in terms of energy savings, and reduction of GHG and pollutant emissions have attracted a lot of attention. This includes the impact of the introduction of new motor vehicle technology such as electric and hybrid vehicles, and the use of biodiesel, electric or hybrid buses in public transit. Among other studies, some evaluate different motor vehicle technologies in North America and Europe [12-14]. Similarly, other studies investigate the impact of bus technologies in Australia, China, Portugal and the United States [15-17]. Furthermore, a life cycle analysis (LCA) was used to assess the technological impacts on GHGs [7,8,10,12-14,18-25].

\subsection{Life Cycle Analysis}

LCA summarizes pollutant and GHG emissions for all life stages from cradle-to-grave. The upstream stages, prior to the operation phase, is associated with vehicle manufacturing, infrastructure construction and fuel production. Few studies have considered downstream stages, disposal and/or recycling, since the emissions are similar for alternative technologies and fuels [19], and the evaluation of waste management and material reuse is quite complicated [20]. A life cycle inventory for a rail system typically includes emissions from vehicle life cycle (vehicle material production, assembly, distribution, operation, maintenance, disposal/recycling), fuel life cycle (feedstock production, feedstock transportation, fuel production), and infrastructure life cycle (station, track and parking construction; operation; station and track maintenance).

In the past, the technology (vehicle) operation stage has been the focus of environmental impact assessments due to the lack of data associated with the other life stages and it is also assumed to contribute the largest 
amount of emissions. Recent studies have shown that a significant portion of emissions is attributed to stages other than vehicle operation. An LCA is a more suitable tool towards making sustainable choices since it looks at the complete carbon footprint of a system.

\subsection{Brief LCA of Different Transportation Modes}

Technology operation for most transportation modes is responsible for the largest portion of life cycle $\mathrm{GHG}$ $[19,21,25]$. For passenger cars, it accounts from $67 \%$ to $74 \%$ of the total life cycle emissions [13], where as the production, distribution and disposal of personal motor vehicles contribute less than $10 \%$ to the life cycle energy and GHG emissions [13].

For bus transit fuelled by diesel and compressed natural gas, operational emissions also dominate life cycle emissions; however, fuel production is the most polluting stage for hydrogen-fuelled buses [15]. Tailpipe emissions make up $79.9 \%$ and $85.7 \%$ of the life cycle emissions for diesel buses and compressed natural gas buses, respectively [16].

In the railway industry, the situation is different. Total life cycle GHG emissions are 2.1 and 1.4 times higher than just operational emissions for HRT and HSR, respectively [22]. A sizeable amount of emissions is associated with infrastructure construction and electricity production combined: about $20 \%$ for heavy rail and $10 \%$ for high speed rail [21]. Although, vehicle manufacturing accounts for only $6 \%$ for HRT and less than $1 \%$ for HSR [22].

\subsection{Life Cycle GHG Emissions of Rail Systems}

For the planned California high speed rail (CAHSR), an electric system, the largest portion of emissions is associated with vehicle operation. For the existing San Francisco Bay Area heavy rail commuter line (Caltrain) running on diesel, the emissions are evenly split between the operation phase and the other life cycle components. In this case, the life cycle emissions of heavy rail are 4 times the HSR: $160 \mathrm{~g} \mathrm{CO}_{2}$-eq/passenger-mile vs. $37 \mathrm{~g}$ $\mathrm{CO}_{2}$-eq/passenger-mile [22].

In a more recent study the effect of using high-speed rail in mitigating climate change in Sweden is studied. The author found that 550,000 tons of GHG per annum by $2025 / 2030$ would be reduced which comes from a shift of freight from truck to rail, and air and road passenger travel to high-speed rail [18]. Overall, HSR consumes less energy and is less polluting than conventional trains due to the features associated with a high-speed train: travelling longer distances with fewer stops, therefore, more uniform speed profile; electric traction; higher power supply voltages, lower passenger loads, etc. [5].
Also, the energy consumption from auxiliary services is negatively correlated with speed although higher speeds are positively correlated with fuel consumption per unit distance [5].

The results of an American study comparing diesel buses, BRT system and LRT system show that the LRT was the most environmentally-damaging due to the production of electricity from fossil fuels [24]. The approach of this study is inappropriate because in the US, transit agencies are not responsible for emissions generated from energy suppliers unless it is generated on their own property. In this case, properly defined system boundaries would make the results more comparable.

\subsection{GHG Emissions of Alternative Rail Technologies}

The electrification of trains requires large capital investments for the additional infrastructure; however, it is one of the most efficient transportation systems as it transfers more than $85 \%$ of the electricity input to the wheels $[7,8]$. Also, the use of renewable resources such as hydropower, solar energy, wind and geothermal energy for electricity production would eliminate the combustion of fossil fuels. This would greatly affect the overall emissions since these energy sources are assumed to have zero emissions from direct use $[1,12,26]$. The life cycle $\mathrm{CO}_{2}$ emissions for diesel-electric hybrid and electric freight trains are 45 $\mathrm{g} /$ tons-km and $44 \mathrm{~g} /$ tons-km, respectively [14].

Fuel cell technology has the potential to reduce GHG emissions generated from internal combustion engines. In general, hydrogen fuel cell vehicles have lower emissions than hydrogen internal combustion engine vehicles. There are a variety of production methods for hydrogen. A few examples are steam methane reforming (SMR), a thermochemical cycle using thermal energy and electrolysis using wind or solar energy. Depending on the method of hydrogen production, the emissions can vary greatly. The most popular method, SMR via electrolysis, emits 5.5 kilogram of $\mathrm{CO}_{2}$ for every kilogram of hydrogen produced [26]. The best method for hydrogen production from an environmental point of view is a combination of renewable energy with the copper-chlorine cycle [10]. This is a thermochemical cycle which decomposes water into hydrogen and oxygen, and requires a high heat requirement. The heat requirement is achieved by burning hydrogen which is produced from renewable energy sources. The process is a closed loop cycle which means that the chemicals are recycled and GHGs are not emitted into the atmosphere. The $\mathrm{CO}_{2}$ emissions of a hydrogen-fuelled passenger train are about $9 \%$ of a diesel train, or an electric train that uses coal to produce electricity [10].

Although it has been established that the use of hydrogen would lead to fuel and energy reductions, it can- 
not be confirmed that they would compensate for the high costs and difficulties with storage [27,28]. The storage of hydrogen gas requires large amounts of space; therefore, the most likely solution is to carry compressed hydrogen in storage tanks. The problem with that is the reactivity of hydrogen and the risk of explosion. This requires the storage tanks to withstand accidental impacts but still remain lightweight which is costly [27].

An in-between solution (between diesel and fuel cell trains) would be to implement hybrid fuel cell technologies until the costs of fuel cell locomotive decrease [28]. This would allow for a more economical transition to a completely fuel cell locomotive [28].

Additionally, some European countries such as Sweden, Norway, Switzerland, and Austria, already obtain a large proportion of energy from clean sources, in particular, hydroelectricity [27]. Under these conditions, it is unlikely that fuel cell technology will be adopted for existing electric rail networks [27]. Nevertheless, hydrogen remains competitive with electricity due to the lower infrastructure costs since additional electrical infrastructure is not required [27]. According to the Strategic Rail Authority, a rail trip in the U.K. generates, on average, 56 $\mathrm{g} \mathrm{CO}_{2} /$ passenger-km for a hydrogen-fuelled train compared with $146 \mathrm{~g} \mathrm{CO}_{2}$ /passenger-km for a private vehicle with 1.3 passengers [27].
Despite the importance of previous works in the literature, few studies have addressed the impact of new technologies in commuting train systems in North America, and, in particular, in Canada. One of the few studies is the GO Transit in Ontario, Canada [7,8,10]. These recent studies have recognized the benefits of hydrogen fuel cell trains including GHG savings and flexibility on existing railways since there is no need for additional infrastructure. A case study in Quebec would demonstrate greater GHG reductions by using renewable electricity supply which is in contrast to the predominance of coal-powered electricity plants in North America. It would be important to verify the viability of hydrogen commuter trains in Montreal, Quebec, given its clean electricity production from hydropower.

\section{Case Study: AMT Commuter Rail Network}

\subsection{Montreal Rail Network}

The commuter rail network in Montreal, a heavy rail system, is operated by the Agence métropolitaine de transport (AMT). The current network comprises of five lines: Vaudreuil-Hudson, Deux-Montagnes, Candiac, Mont-Saint-Hilaire and Blainville-Saint-Jérôme, which serve the Montreal metropolitan area (Figure 2). Diesel

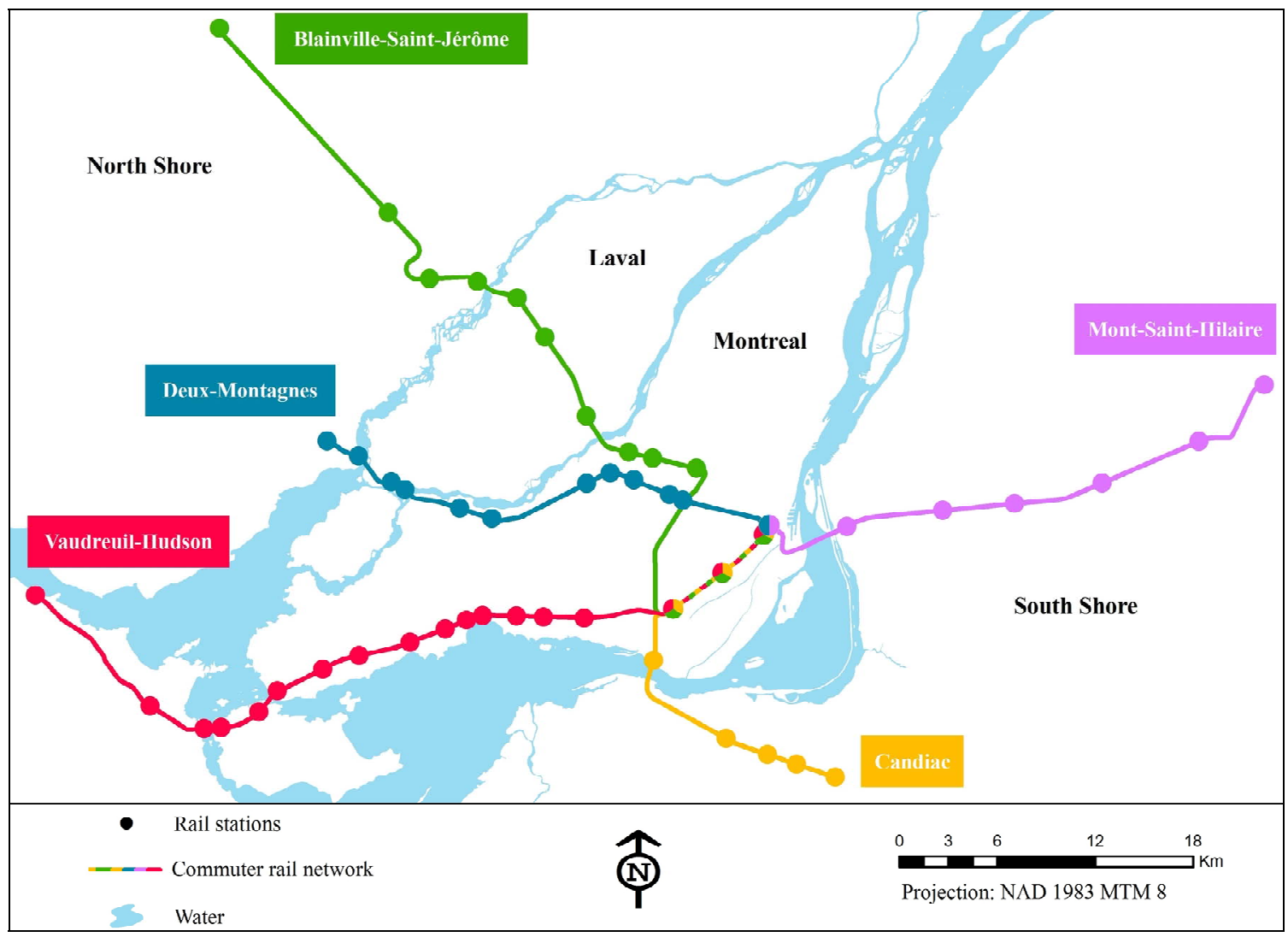

Figure 2. Commuter rail network in Montreal. 
trains travel on all lines except for Deux-Montagnes, the only electrified line with a length of 29.9 kilometers. Deux-Montagnes has been running electric trains since its beginning (in 1906) due to the poor ventilation in the Mont-Royal tunnel. The reference case refers to the diesel-powered trains operating on four rail lines and the electric-powered trains running on one rail line.

Construction is underway to extend the network on the east side of Montreal; the sixth line will be called the Mascouche line. Dual-mode locomotives have already been purchased for the Mascouche line. This line also passes through the Mont-Royal tunnel; therefore, partial electrification is necessary. A feasibility study on the electrification of the AMT commuter rail is in progress. The features of the AMT commuter rail are presented in Table 1.

\subsection{Electricity Production in Quebec}

It is important to mention that Hydro-Quebec has a long standing history in Quebec's economic development, and is continuously involved in numerous large-scale hydroelectric projects. Hydro-Quebec is the main supplier of electricity in Quebec. It is also the world's largest hydroelectricity producer with 60 hydroelectric generating stations and a total capacity of 36,700 megawatts [29].

Electricity in Quebec is generated from various sources: $91 \%$ from hydro, $4 \%$ from oil, $2 \%$ from nuclear, $1 \%$ from natural gas and $2 \%$ from other sources [30]. It is highly unlikely that the predominance of hydropower in Quebec's electricity composition will change in the foreseeable future. The clean electricity production is comparable to several countries in Europe. In contrast, $30 \%$ of electricity is generated from coal and only $9 \%$ from hydro in the United States. In Canada, 22\% and $59 \%$ of electricity is produced from coal and hydro, respectively.

\section{Scope and Limitations}

From the literature, the emissions from vehicle manufacturing of rail transit are not as important as the fuel and infrastructure life cycles [22]. In a complementary study

Table 1. Features of the Montreal commuter rail network.

\begin{tabular}{l} 
Characteristics \\
\hline Rail lines: 5 \\
Stations: 51 \\
Track length: $204.4 \mathrm{~km}$ \\
Diesel locomotives: 39 \\
Weekday ridership: 71,900 passengers \\
\hline
\end{tabular}

by the same authors, the vehicle manufacturing phase for a passenger car is about $8 \%$ [4]. It is expected that this proportion would be even smaller for trains if they operate all day compared to a car which runs a fraction of that time. Although emissions from additional electrical infrastructure are not negligible, it is minimal with respect to the total emissions over time. Only one study was found which indicates such low proportions with regards to life cycle emissions [22]. Furthermore, the rail infrastructure already exists and the alternative scenarios do not entail developing a new rail network from scratch. In the absence of life cycle studies of rail infrastructure, calculation for emissions from infrastructure construction is omitted.

Market analysis is also beyond the scope of the paper. It is unknown how electrification of an existing rail network would affect the capacity or the demand of existing dams and reservoirs or even the composition of electricity. Therefore, it is assumed that the current set of electricity generating stations in Quebec is able to sustain a full electrification of Montreal's commuter rail. For these reasons, the analysis will be limited to emissions from vehicle operation and fuel production.

Given the importance of hydroelectricity in Quebec, it would not be valuable to consider other electric subconfigurations. The paper will analyze, among others, these two extreme cases: current scenario of diesel technology (with one existing electrified line) and complete electrification. Partial electrification scenarios can be roughly estimated by taking proportions from the two extreme values. These cases can be investigated further in the future.

The estimation of GHG emissions relies on linear coefficients and assumes constant parameters across time and loads. Furthermore, fuel and electricity consumption are based on single values of system efficiency. It would be more robust to carry out a sensitivity analysis on a range of system efficiencies, specifically for the hydrogen fuel cell system, a hypothetical technology. This has been left as future research.

\section{Methodology}

The quantification of the GHGs in $\mathrm{CO}_{2}$-equivalent for the current situation and the alternative scenarios is described in this section. GHG emissions were estimated for five different scenarios: 1) base case; 2) complete electrification; 3) hydrogen fuel cell by SMR; 4) hydrogen fuel cell using wind energy; and 5) changes in ridership.

In order to estimate GHG emissions of the various technologies, Equation (1) was used, where GHG is the emissions in $\mathrm{CO}_{2}$-equivalent, $E F$ is the emissions factor, $C$ is energy or fuel consumption depending on the technology and VKT is the vehicle kilometers traveled. The 
global warming potentials used were 21 for methane and 310 for nitrous oxide [31]. Total GHG emissions include direct emissions from the operation phase and indirect emissions from fuel production or electricity generation.

$$
G H G=E F \times C \times V K T
$$

Table 2 lists the emission factors for direct and indirect use of hydrogen fuel produced by SMR and wind energy [9], diesel fuel and electricity [32]. The direct emission factor for diesel heavy rail is a general emission rate that does not take into account the specific diesel technology being used. For electric and hydrogen trains, there are no emissions during operation. The indirect emission factor of electricity production is specific to Quebec and its electricity mix, and is based on activities that occurred at the electricity generating station only [33]. An LCA of hydrogen fuel cell systems indicate that GHG emissions can be restricted by using different energy sources [9]. Hydrogen production by SMR involves the transportation of natural gas from extraction to the power plant, and then from the power plant to refueling stations. In contrast, hydrogen from wind or solar energy is produced via electrolysis at fueling stations. Both production methods involve hydrogen compression. These processes, as well as the electricity generation from wind turbines, are embedded in the emission factors for hydrogen fuel production.

The annual diesel fuel consumption and the electricity consumption of the AMT commuter rail network (Figure 3) as well as the total passenger-kilometers, vehiclekilometers and train-kilometers traveled for each rail line for the years 2005-2008 were supplied by the AMT. Although VKT has increased over the years, the diesel and electricity consumptions have decreased due to the regular renewal of the fleet to newer and more efficient rolling stock [34]. For the reference case, observed fuel and electricity consumption rates in 2008 were used to calculate emissions. For the electrification case, it was assumed that the entire network would have an electricity consumption rate consistent with the current DeuxMontagnes line.

For hydrogen fuel cell powered trains, a different approach was taken since the fuel consumption rate is not available. The consumption rate was estimated by con-

Table 2. $\mathrm{CO}_{2}$-eq emission factors and direct costs by technology.

\begin{tabular}{lccc}
\hline Technology & Direct Use & Indirect Use & Direct Cost \\
\hline Diesel & $3007 \mathrm{~g} / \mathrm{L}$ & $724 \mathrm{~g} / \mathrm{L}$ & $\$ 1.071 / \mathrm{L}$ \\
Electric (hydro) & 0 & $2.5 \mathrm{~g} / \mathrm{MJ}$ & $4.78 \phi / \mathrm{kWh}$ \\
H2 Fuel Cell (SMR) & 0 & $84.8 \mathrm{~g} / \mathrm{MJ}$ & \\
H2 Fuel Cell (wind energy) & 0 & $20.55 \mathrm{~g} / \mathrm{MJ}$ & $\$ 35 / \mathrm{GJ}$ \\
\hline
\end{tabular}
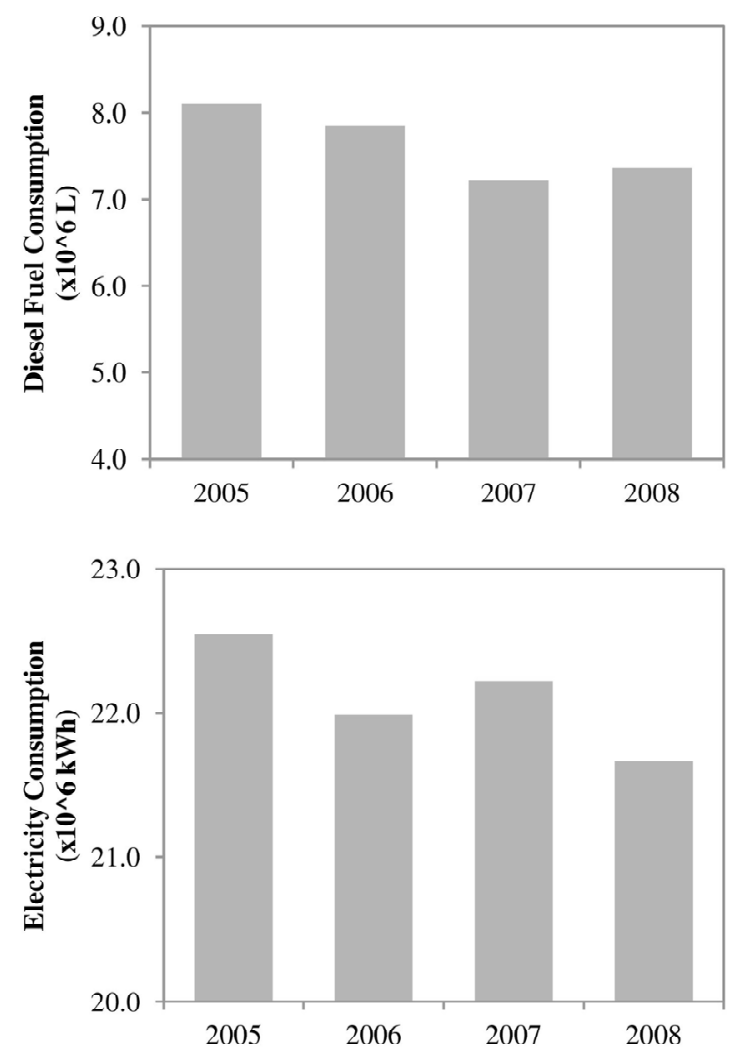

Figure 3. Diesel fuel and electricity consumption of AMT.

sidering the efficiency of a hydrogen fuel cell system. When one liter of diesel is burnt, 38.65 megajoules of energy is released [32]. In 2008, the average diesel fuel consumption rate for AMT trains was $11.5 \mathrm{~L} / \mathrm{km}$. With an efficiency of $24 \%$ for diesel engines [35], the power output is $106.7 \mathrm{MJ} / \mathrm{km}$. It is assumed that a hydrogen train would require the same amount of power to travel the same distance; however, fuel cell powertrains have a system efficiency of $50 \%$ [35]. The energy consumption of the hydrogen fuel cell train is $(106.7 / 0.50)=213.3$ $\mathrm{MJ} / \mathrm{km}$. Two hydrogen production methods were considered: SMR and another using renewable energy source to obtain comparable results with hydroelectricity generation. The emission factors were then applied to convert energy consumption to GHG emissions per $\mathrm{km}$.

\section{Results and Discussion}

\subsection{GHGs of Alternative Technologies}

Figures 4 and 5 illustrate the GHG emissions for the base case scenario and the alternative technologies. The conversion of the current fleet to all electric trains would reduce GHG emissions by $98 \%$ which is more than 27,000 tons/year. In contrast, the emissions savings from the reference case to hydrogen fuel cell scenarios are not as outstanding but still significant. An annual decrease of about 6600 tons and 22,600 tons is expected for the 


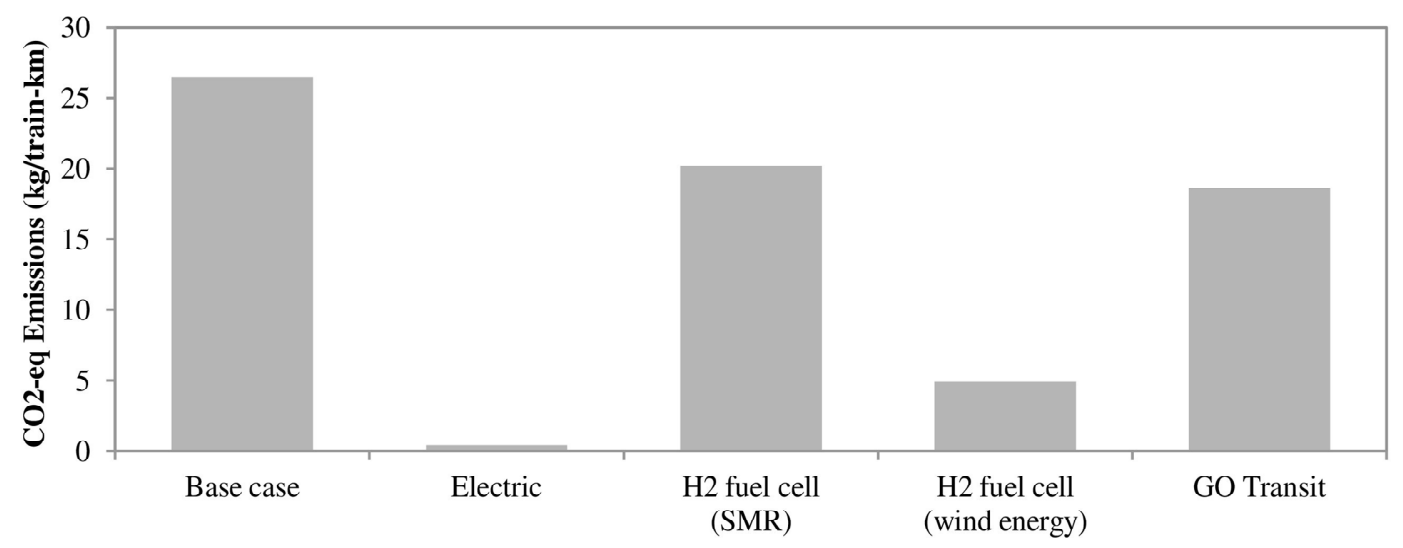

Figure 4. Annual GHG emissions by technology per train-km.

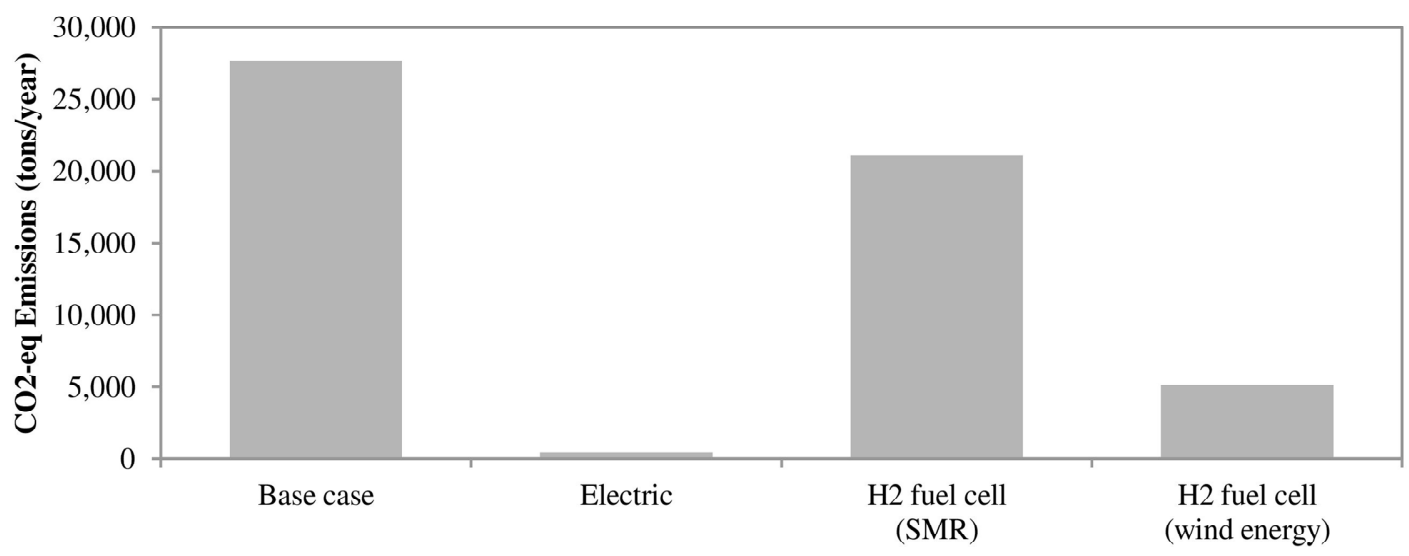

Figure 5. Total annual GHG emissions by technology.

cases where hydrogen is produced by SMR and from wind energy, respectively. Even though the fuel cell train using hydrogen produced from wind energy is a cleaner technology than diesel-fuelled trains, annual GHG emissions are still 8 times that of electric trains. Using renewable energy sources provide the greatest reduction in GHG emissions as demonstrated by trains powered by hydroelectricity and by hydrogen produced from wind energy.

Calculations were also carried out for the GO Transit, the commuter rail in Toronto, Ontario, for comparison. It is noticeable that the GO Transit is less GHG polluting than the AMT commuter rail: $26.5 \mathrm{~kg} /$ train-km vs. 18.7 $\mathrm{kg} /$ train- $\mathrm{km}$ even though their fleet is entirely composed of diesel-powered trains. This discrepancy can be explained by the large difference between the fuel consumption of the commuter rail systems. For the GO Transit, it was assumed to be $5 \mathrm{~L} /$ train- $\mathrm{km}[7,8,10]$. As mentioned earlier, from recorded observations, the fuel consumption was $11.5 \mathrm{~L} /$ train-km for the AMT trains. In 2011, GO Transit completed a four-year plan to replace the old F-59 with the new MP40 locomotives, which meets the US Environmental Protection Agency Tier 2 Emission Standards [11].

\subsection{GHGs Reduction by Increasing Ridership}

Ridership management is achieved through policies encouraging transit use. A shift from automobile use to rail transit would reduce emissions per passenger but not total emissions of a commuter rail. It would be interesting to compare the different levels of ridership for each case for a given GHG emission per passenger. This would determine whether increasing ridership would be a better (or possible) solution than changing technologies to reduce GHG emissions in the transportation sector. It is assumed that ridership would not change with different fuel types.

Prior to comparing ridership levels, the emissions from the previous section have been normalized to per passenger-kilometer travelled (PKT). The capacity of one EMU from the Deux-Montagnes line is 214 passengers: 88 seated and 126 standing [36]. A range of ridership was considered from low occupancy $(10 \%)$ to full occupancy that is 21.4 to 214 passengers per train vehicle as shown in Figure 6.

For example, at GHG emissions of $28.5 \mathrm{~g} \mathrm{CO}_{2}$-eq/ passenger-km, the ridership per train vehicle is 115.8 passengers for the base case, 88.3 passengers for the hy- 


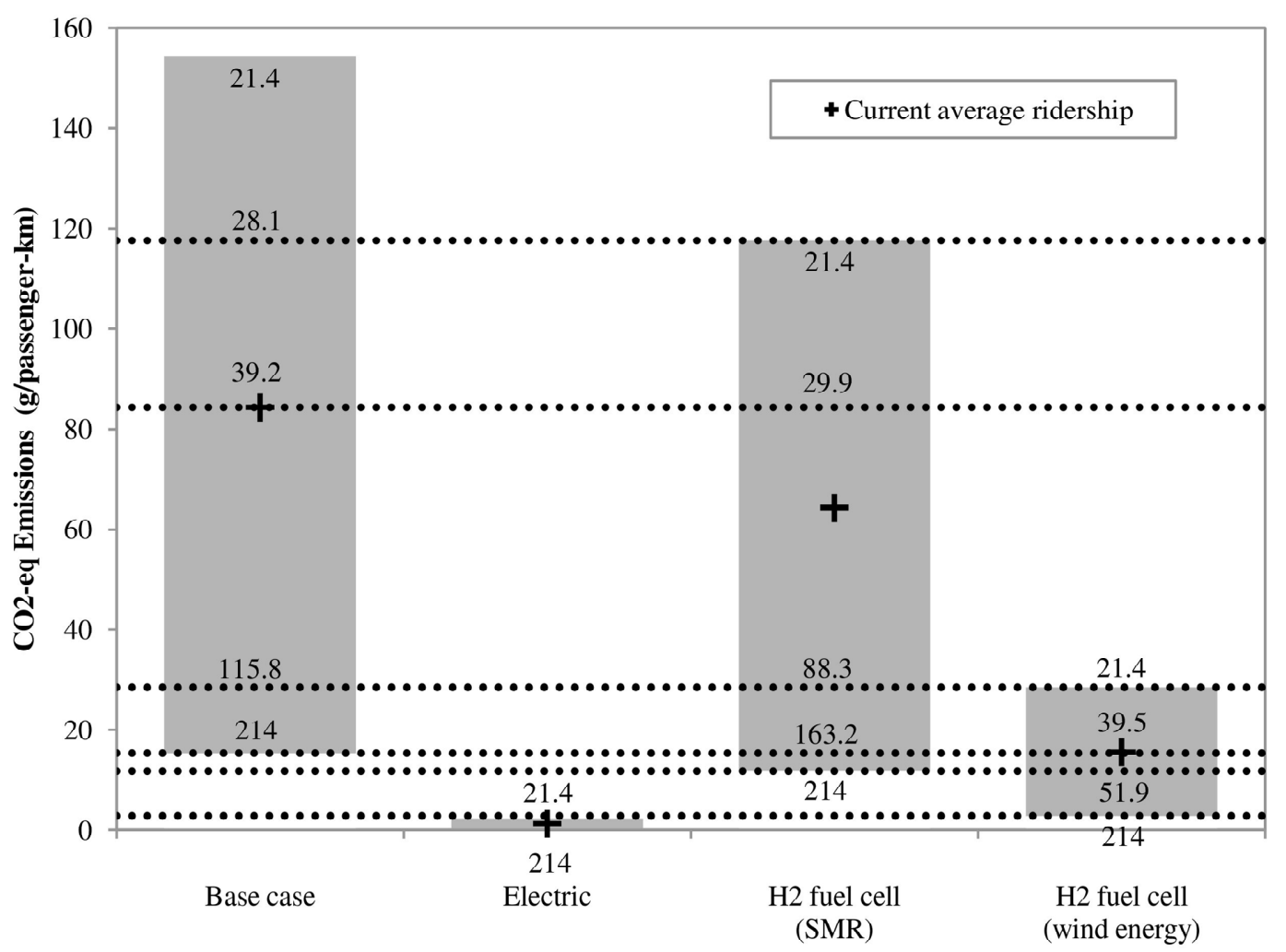

Figure 6. Annual GHG emissions per PKT for a range of ridership level.

drogen fuel cell using SMR case and 21.4 passengers for the hydrogen fuel cell using wind energy case. The current average occupancy is 39.2 passengers per train vehicle. This figure would have to almost triple for the current diesel technology to equate to the GHG levels of the fuel cell technology using wind energy corresponding to a $10 \%$ occupancy rate.

Increasing ridership for the commuter rail by 2-3 times is unlikely; therefore, a more reasonable solution to reduce GHG emissions is by switching to a cleaner technology. It can also be seen that given the low emissions from electric trains, the emissions from the current network will always be higher than a full electrification of the network even at full passenger occupancy for the reference case. Similarly, all technologies have GHG emissions higher than that of electrification for all ridership levels.

If the electricity generation was coal-based or natural gas-based, the emissions would be much higher for the electrification case. In addition, hydrogen fuel cell trains would probably be the cleanest technology.

\subsection{Operating and Capital Costs of Alternative Technologies}

Based on environmental impact, it is clear that electric trains are the most sustainable choice; yet, cost analysis is imperative to determine the most appropriate decision towards sustainability. All costs are expressed in Canadian currency, unless otherwise stated.

\subsubsection{Operating Costs}

The operating costs are defined here as the cost from direct fuel and electricity consumption as listed in Table 2. The price of diesel fuel including taxes in Montreal is $\$ 1.071 / \mathrm{L}$ which is much higher than the national average of $\$ 1.008 / \mathrm{L}$ [37]. The differences are mainly due to higher fuel taxes in Montreal than the rest of Canada. The low cost of hydroelectricity refers to the average price for large-power customers in Montreal [38]. Regardless of the method of hydrogen production, the cost of hydrogen gas is approximately \$35/GJ [10].

Due to the low cost of electricity in Quebec, it would not be suitable to apply these operating costs to other cities where electricity can cost 2-3 times as much as in Quebec. For example, the cost of electricity for largepower consumers is $9.75 \notin / \mathrm{kWh}$ in Toronto, Ontario, and $12.64 \phi / \mathrm{kWh}$ in New York, New York [38]. However, unless the electricity costs were to be raised to at least $13.96 \notin / \mathrm{kWh}$, the operating costs of electricity would still be the cheapest option.

Based on these figures, it is most economical to operate electric trains which are 3 times and 6 times cheaper than operating hydrogen fuel cell trains and the current scenario, respectively (Figure 7). 


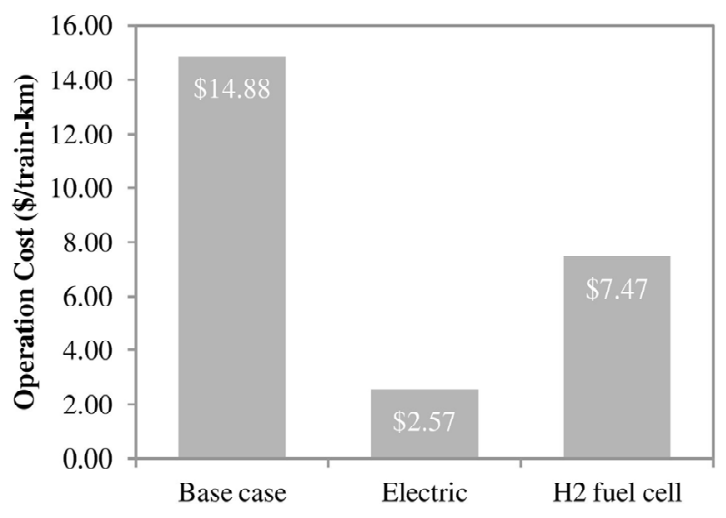

Figure 7. Operation costs by technology.

\subsubsection{Capital Costs}

In addition to fuel and electricity costs, capital costs for infrastructure and rolling stock must be considered.

1) Complete Electrification Case

In Canada, the GO Transit serving the Greater Toronto and Hamilton Area (GTHA) in Ontario is most similar to the AMT commuter rail in terms of coverage area, ridership level and technology [39]. Accordingly, electrification costs of the Montreal commuter rail will be based on figures estimated for the GO Transit.

A feasibility report by the GO Transit in Ontario estimates a cost of $\$ 3.8$ billion for the electrification of the entire network (total of 508.9 kilometers of track after corridor extensions) [40]. The infrastructure capital costs were estimated prior to any detailed design work; therefore, a $35 \%$ contingency is included to capture potential additional costs. A contingency plan was not considered for the rolling stock which entails the acquisition of 107 electric locomotives and 12 EMUs. Also, the maintenance costs of electric infrastructure and rolling stock is included in the infrastructure costs. The breakdown of the capital costs of electrification of the GO Transit is shown in Table 3.

In other words, the cost of infrastructure electrification with contingency is about $\$ 5.932$ million $/ \mathrm{km}$ of track and $\$ 5.945$ million for each electric locomotive. In comparison, a study for the VLTJ proposes a more modest figure at $€ 0.4-0.9 \mathrm{million} / \mathrm{km}$ [41] which converts to an average of $\$ 0.88 \mathrm{million} / \mathrm{km}[42]$. The costs of electrification of the AMT commuter rail are based on figures of the GO Transit; in this case, 174.5 kilometers of track need to be electrified. These estimates are comparable to the proposed cost of $\$ 1.2-1.5$ billion by the Quebec government in a feasibility report [43] that has been requested but not yet available (Table 4).

\section{2) Hydrogen Fuel Cell Case}

With the hydrogen fuel cell technology, the majority of capital costs are due to the rolling stock. According to a feasibility study on hydrogen trains by Rail Safety and Standards Board (RSSB) in the UK, the costs are £9-10
Table 3. Estimated capital costs of GO transit electrification.

\begin{tabular}{cc}
\hline & Costs (\$ millions) \\
\hline Catenary system & 615 \\
Power supply system & 277 \\
Maintenance \& layover facilities, vehicles & 136 \\
Overhead structures rework & 312 \\
Infrastructure rework & 126 \\
Sitework \& special conditions & 576 \\
Professional services & 193 \\
Sub-total (without contingency) & 2236 \\
Sub-total (with 35\% contingency) & 3019 \\
Rolling stock & 736 \\
Total (with 35\% contingency) & 3755 \\
\hline
\end{tabular}

Table 4. Comparison of operation and capital costs of AMT commuter rail.

\begin{tabular}{ccc}
\hline & $\begin{array}{c}\text { Electrification } \\
\text { (\$ millions) }\end{array}$ & $\begin{array}{c}\text { Hydrogen Fuel Cell } \\
\text { (\$ millions) }\end{array}$ \\
\hline Infrastructure + Maintenance & 1035.1 & 75.9 \\
Rolling Stock & 231.9 & 571.4 \\
Operation & 2.7 & 7.8 \\
Total & 1269.7 & 655.1 \\
\hline
\end{tabular}

million for a fuel cell locomotive [35]. This translates to an average of \$14.65 million for each hydrogen locomotive [42]. Although a hydrogen locomotive is twice as expensive as an electric locomotive, this is more than offset by savings from infrastructure construction as shown in Table 4.

Due to the lack of information on maintenance costs of hydrogen fuel cell trains, it has been assumed that they are equivalent to diesel trains [35]. Although fuel cells are more reliable than internal combustion engines, the additional maintenance resources required would balance out these savings [35]. The maintenance costs, at $\$ 0.435$ million $/ \mathrm{km}$, are taken from the GO Transit feasibility report [40]. Note that it is less expensive to maintain electric locomotives than diesel locomotives [40].

According to the capital and overall costs, hydrogen trains would be the best scenario for implementation. It is however a new technology and further testing is required to prove its feasibility. There are also issues with storage and commercial availability of hydrogen gas that need to be resolved. 


\subsection{Market Price of $\mathrm{CO}_{2}$}

The European Union Emissions Trading System (EU ETS) was launched in 2005 with the goal of reducing industrial GHG emissions. It is based on the cap-andtrade principle in which industries have a limit on GHG emissions and receive allowances within this limit. Fines are imposed if the allowances, which are worth 1000 tons of $\mathrm{CO}_{2}$-equivalent, do not cover all its emissions. These allowances are sold or bought as needed from other industries at the market price [44].

The price of $\mathrm{CO}_{2}$ is determined by many factors such as energy prices and climate [45]. From 25 theoretical models of the carbon market, the price varies from 1-74 USD per ton of $\mathrm{CO}_{2}$-equivalent [46]. The forecasted market price of a $\mathrm{CO}_{2}$ allowance for the summer of 2011 is $€ 15.75$ [47] or $\$ 21.48$ [42]. Using the market price of carbon and the annual tons of GHG emissions for each technology, the cost of $\mathrm{CO}_{2}$-equivalent emissions are calculated (Table 5). These costs are marginal compared to operation, rolling stock and infrastructure costs. Electric-powered trains with the lowest emissions would cost less than $\$ 10$ whereas the base case scenario would cost as much as $\$ 600$ annually.

\section{Conclusions}

The paper examined the impact of technology and ridership changes on GHG emissions for the commuter rail in Montreal. These alternative technologies were considered: complete electrification, hydrogen fuel cell using SMR and hydrogen fuel cell using wind energy. A technology change for the commuter rail system cannot be considered solely from an environmental impact analysis. Other factors such as operation and infrastructure costs, and technological and commercial viability was also considered.

A full electrification of the commuter rail network would lead to the greatest GHG reduction which is more than 27,000 tons/year. This is a decrease of $98 \%$ from the current scenario. The electrification case is also associated with the lowest operating cost at $\$ 2.57 /$ train-km. It seems evident that converting to electric-powered trains is the appropriate course of action. This is primarily due to Quebec's unique energy source which is almost exclusively of hydroelectricity. It is also noteworthy that even

Table 5. Annual cost of GHG emissions.

\begin{tabular}{rc}
\hline Technology & Cost of GHGs \\
\hline Base case & $\$ 594$ \\
Electric & $\$ 9$ \\
H2 fuel cell (SMR) & $\$ 453$ \\
H2 fuel cell (wind energy) & $\$ 109$ \\
\hline
\end{tabular}

if policies to encourage rail transit use reached its full potential, the GHG emissions of the reference case would still be higher than the electrification case at the lowest occupancy.

Despite these benefits, electric infrastructure including overhead catenary and power substations are very expensive. In view of that, hydrogen-powered trains can be competitive with electric-powered trains. The implementation of hydrogen fuel cell commuter rail does not require the construction of infrastructure for power supply and distribution. Hence, the capital costs would mostly take into account the rolling stock. Hydrogen trains are twice as expensive as electric trains; however, the overall cost is significantly lower than the electrification case. For the conversion of the entire AMT commuter rail, the costs are $\$ 1.3$ billion for electrification compared with $\$ 655$ million, on average, for a hydrogen fuel cell system.

Feasibility studies of hydrogen trains are in progress in Japan, Denmark and Canada. Until this technology has been thoroughly tested, the implementation of hydrogen commuter rail would be premature and risky. Difficulties with storage should be resolved and risk of explosion should be mitigated.

\section{Acknowledgements}

We acknowledge the financial support of the Fonds québécois de la recherche sur la nature et les technologies (FQRNT).We would also like to thank AMT for providing the data. All remaining errors and the views expressed in this research are, however, solely ours.

\section{REFERENCES}

[1] R. A. Smith, "Railways: How They May Contribute to a Sustainable Future," Proceedings from the Institution of Mechanical Engineers, Part F: Journal of Rail and Rapid Transit, United Kingdom, Vol. 217, No. 4, 2003, pp. 243248. doi:10.1243/095440903322712847

[2] Transportation Research Board, "Highway Capacity Manual," National Research Council, Transportation Research Board, Washington DC, 2000.

[3] E. W. Walbridge, "Energy Consumption, Pollutant Production, and Dollar Costs of Diesel Suburban Commuter Trains," Transportation, Vol. 5, No. 3, 1976, pp. 285-307. doi:10.1007/BF00148380

[4] M. Chester and A. Horvath, "Environmental Life-cycle Assessment of Passenger Transportation: A Detailed Methodology for Energy, Greenhouse Gas and Criteria Pollutant Inventories of Automobiles, Buses, Light Rail, Heavy Rail and Air v.2," UC Berkeley Center for Future Urban Transport: A Volvo Center of Excellence, Institute of Transportation Studies, UC Berkeley, Berkeley, 2008.

[5] A. G. Alvarez, "Energy Consumption and Emissions of High-Speed Trains," Transportation Research Record: 
Journal of the Transportation Research Board, Vol. 2159, 2010, pp. 27-35. doi:10.3141/2159-04

[6] B. Rutzen, N. Hutson and L. Loftus-Otway, "Mexico City, Mexico, Commuter Rail. Planning and Implementation of Multijurisdictional, Public-Private Partnership Project," Transportation Research Record: Journal of the Transportation Research Board, Vol. 2146, 2010, pp. 119-126. doi: $10.3141 / 2146-15$

[7] G. D. Marin, G. F. Naterer and K. Gabriel, "Rail Transportation by Hydrogen vs. Electrification-Case Study for Ontario Canada, I: Propulsion and Storage," International Journal of Hydrogen Energy, Vol. 35, No. 12, 2010, pp. 6084-6096. doi:10.1016/j.ijhydene.2010.03.098

[8] G. D. Marin, G. F. Naterer and K. Gabriel, "Rail Transportation by Hydrogen vs. Electrification - Case Study for Ontario, Canada, II: Energy Supply and Distribution," International Journal of Hydrogen Energy, Vol. 35, No. 12, 2010b, pp. 6097-6107. doi:10.1016/j.ijhydene.2010.03.095

[9] I. Dincer, "Environmental and Sustainability Aspects of Hydrogen and Fuel Cell Systems," International Journal of Energy Research, Vol. 31, No. 1, 2007, pp. 29-55. doi:10.1002/er.1226

[10] Y. Haseli, G. F. Naterer and I. Dincer, "Comparative Assessment of Greenhouse Gas Mitigation of Hydrogen Passenger Trains," International Journal of Hydrogen Energy, Vol. 33, No. 7, 2008, pp. 1788-1796. doi:10.1016/i.ijhydene.2008.02.005

[11] LTK Engineering Services, "Rolling Stock Technology Assessment for Metrolinx GO Electrification," Metrolinx, Ambler, 2010.

[12] N. Zamel and X. Li, "Life Cycle Analysis of Vehicles Powered by a Fuel Cell and by Internal Combustion Engine for Canada," Journal of Power Sources, Vol. 155, No. 2, 2006, pp. 297-310. doi:10.1016/j.jpowsour.2005.04.024

[13] A. Schafer, J. B. Heywood and M. A. Weiss, "Future Fuel Cell and Internal Combustion Engine Automobile Technologies: A 25-Year Life Cycle and Fleet Impact Assessment," Energy, Vol. 31, No. 12, 2006, pp. 2064-2087. doi:10.1016/j.energy.2005.09.011

[14] B. V. Wee, P. Janse and R. Van Den Brink, "Comparing Energy Use and Environmental Performance of Land Transport Modes," Transportation Research, Vol. 25, No. 1, 2005, pp. 3-34. doi:10.1080/014416410001676861

[15] J. Ally and T. Pryor, "Life-cycle Assessment of Diesel, Natural Gas and Hydrogen Fuel Cell Bus Transportation Systems," Journal of Power Sources, Vol. 170, No. 2, 2007, pp. 401-411. doi:10.1016/j.jpowsour.2007.04.036

[16] D. Karman, "Life-Cycle Analysis of GHG Emissions for CNG and Diesel Buses in Beijing," EIC Climate Change Technology, Ottawa, 10-12 May 2006, pp. 248-253.

[17] H. C. Frey, N. M. Rouphail, H. Zhai, T. L. Farias and G. A. Goncalves, "Comparing Real-world Fuel Consumption for Diesel- and Hydrogen-Fueled Transit Buses and Implication for Emissions," Transportation Research Part D, Vol. 12, No. 4, 2007, pp. 281-291. doi:10.1016/j.trd.2007.03.003

[18] J. Akerman, "The Role of High-Speed Rail in Mitigating
Climate Change- The Swedish Case Europabanan from a Life Cycle Perspective," Transportation Research Part D, Vol. 16, No. 3, 2011, pp. 208-217. doi:10.1016/j.trd.2010.12.004

[19] P. S. Castella, I. Blanc, M. G. Ferrer, B. Ecabert, M. Wakeman, J.-A. Manson, D. Emery, S.-H. Han, J. Hong and O. Jolliet, "Integrating Life Cycle Costs and Environmental Impacts of Composite Rail Car-Bodies for a Korean Train," The International Journal of Life Cycle Assessment, Vol. 14, No. 5, 2009, pp. 429-442. doi:10.1007/s11367-009-0096-2

[20] M. V. Chester and A. Horvath, "Environmental Assessment of Passenger Transportation Should Include Infrastructure and Supply Chains," Environmental Research Letters, Vol. 4, No. 2, 2009, pp. 1-8. doi:10.1088/1748-9326/4/2/024008

[21] M. Chester and A. Horvath, "Life-Cycle Assessment of High-Speed Rail: The Case of California," Environmental Research Letters, Vol. 5, No. 1, 2010, pp. 1-8. doi:10.1088/1748-9326/5/1/014003

[22] A. Horvath and M. Chester, "Environmental Life-Cycle Assessment of Passenger Transportation: An Energy, Greenhouse Gas, and Criteria Pollutant Inventory of Rail and Air Transportation," University of California Transportation Center, UC Berkeley, Berkeley, 2008.

[23] M. Lenzen, "Total Requirements of Energy and Greenhouse Gases for Australian Transport," Transportation Research Part D, Vol. 4, No. 4, 1999, pp. 265-290. doi:10.1016/S1361-9209(99)00009-7

[24] W. Vincent and L. C. Jerram, "The Potential for Bus Rapid Transit to Reduce Transportation-Related $\mathrm{CO}_{2}$ Emissions," Journal of Public Transportation, Vol. 9, No. 3, 2006, pp. 219-237.

[25] C. von Rozycki, H. Koeser and H. Schwarz, "Ecology Profile of the German High-Speed Rail Passenger Transport System, ICE," The International Journal of Life Cycle Assessment, Vol. 8, No. 2, 2003, pp. 83-91. doi:10.1007/BF02978431

[26] D. Meegahawatte, S. Hillmansen, C. Roberts, M. Falco, A. McGordon and P. Jennings, "Analysis of a Fuel Cell Hybrid Commuter Railway Vehicle," Journal of Power Sources, Vol. 195, No. 23, 2010, pp. 7829-7837. doi:10.1016/j.jpowsour.2010.02.025

[27] S. Hillmansen, "The Application of Fuel Cell Technology to Rail Transport Operation," Proceedings from the Institution of Mechanical Engineers, Part F: Journal of Rail and Rapid Transit, Vol. 217, No. 4, 2003, pp. 291-298. doi: $10.1243 / 095440903322712900$

[28] B. A. Steinberg and D. S. Scott, "Hydrogen vs. Diesel Fueled Locomotives: A Techno-Economic Appraisal," International Journal of Hydrogen Energy, Vol. 9, No. 1-2, 1984, pp. 101-107. doi:10.1016/0360-3199(84)90037-5

[29] Hydro-Quebec, “Annual Report 2010," Hydro-Quebec, Montreal, 2011.

[30] Hydro-Quebec, "Sustainability Report 2010," HydroQuebec, Montreal, 2011.

[31] CSA Climate Change \& GHG Registries, "Challenge Re- 
gistry Guide to Entity and Facility-Based Reporting," CSA Climate Change \& GHG Registries, Ottawa, 2009.

[32] Transport Canada, "GHG Emission Factors," 2008. http://wwwapps.tc.gc.ca/Prog/2/UTEC-CETU/GhgEmissi onFactors.aspx?lang=eng

[33] Environment Canada, "National Inventory Report 19902005: Greenhouse Gas Sources and Sinks in Canada," Environment Canada, Gatineau, 2007.

[34] AMT, "Rapport Annuel 2008," AMT, Montreal, 2009.

[35] AEA Technology Rail, "Feasibility Study into the Use of Hydrogen Fuel Final Report," Rail Safety and Standards Board, London, 2005.

[36] "Electric Multiple Unit Technical Sheet," Bombardier Inc., Transportation Equipment Group, St-Bruno, 2000.

[37] Natural Resources Canada, "Diesel Prices," 2010. http://www.nrcan.gc.ca/eneene/pripri/diedie-eng.php

[38] Hydro-Quebec, "Comparison of Electricity Prices in Major North American Cities," 2010. http://www.hydroquebec.com/publictions/en/comparison prices/index.html

[39] GO Transit, "What Is Go?" 2011. http://www.gotransit.com/public/en/aboutus/whatisgo.asp $\mathrm{x}$

[40] Delcan/Arup, "GO Electrification Study Final Report,"
Metrolinx, Toronto, 2010.

[41] H2 Logic, HIRC and Danish Technological Institute, "The Hydrogen Train Feasibility Study: Main report," HIRC, Denmark, 2006.

[42] XE, "Currency Converter Widget," 2011. http://www.xe.com/ucc/

[43] B. Bisson, "Québec Electrifiera les Trains de Banlieue," 2011.

http://www.cyberpresse.ca/actualites/regional/montreal/2 01106/09/01-4407797-quebec-electrifiera-les-trains-de-ba nlieue.php

[44] European commission, "Emissions Trading System," 2010. http://ec.europa.eu/clima/policies/ets/index_en.htm

[45] M.M. Ballater, A. Pardo and E. Valor, " $\mathrm{CO}_{2}$ Prices, Energy and Weather," International Association for Energy Economics, Vol. 28, No. 3, 2007, pp. 73-92.

[46] U. Springer, "The Market for Tradable GHG Permits under the Kyoto Protocol: A Survey of Model Studies," Energy Economics, Vol. 25, No. 5, 2003, pp. 527-551. doi:10.1016/S0140-9883(02)00103-2

[47] Reuters, "Analysis: EU Carbon Prices Steady or up Slightly over Summer," 2011.

http://www.reuters.com/article/2011/05/05/us-carbon-pric e-idUSTRE7442TI20110505 